\title{
The Influence of Debt Financing on Firms' Performance: Empirical Evidence from Malaysia
}

\author{
Adam Thompson Tan, Chan Nyet Joo, Jong Chung Wei, Lee Yien Yien, Ying Sii Jin \\ Faculty of Economics and Business, Universiti Malaysia Sarawak
}

\begin{abstract}
This study investigated the relationship between the listed firms' debt level and performance in Bursa Malaysia during a five-year period. Based on the results of the Hausman test and Breusch-Pagan LM test, the fixed-effect model is the most appropriate model that used to analyze the panel data of 50 Malaysian listed companies within the property sector from the year 2015 to 2019. The results indicated that the short-term debt (STD) and long-term debt (LTD) have positive and insignificant effects on return on asset (ROA), which means that the increase in the short-term debt and long-term debt will lead to an increase in the return on assets. Besides that, account payables (AP) has a negative and insignificant effect on the profitability of property sector companies. According to the outcome of the Granger Causality test, the return on assets does not affect by the account payables, short-term debt, long-term debt and firm size. There is only one unidirectional causality relationship that proves that short-term debt is affected by long-term debt. Additionally, this study focuses on enhancing the existing empirical knowledge of debt financing's influence on the profitability of the listed firms in the property sector.
\end{abstract}

Keywords: Debt financing, Firm performance, Return on asset, Bursa Malaysia, Property sector

\section{INTRODUCTION}

\section{Background of the Study}

In emerging economies, laws and regulations related to accounting requirements, information disclosure, and securities transactions are unable to operate efficiently. These problems are created new opportunities for managers to manipulate debt financing for seeking benefits at the cost of shareholders (Pham \& Nguyen, 2020). There will be two types of debt financing which are long-term debt and short-term debt. Long-term debt financing indicates total debt repayable beyond one year while short-term debt requires companies to obtain capital quickly within one year (Salim \& Yadav, 2012).

Aziz and Abbas (2019) indicated that capital structure is a mixture of debt and equity that the companies use in the business operations to maximize the value of a company. If the capital structure was organized well by a company, it will decrease the cost of capital which may increase the value of the company. Besides that, it also will affect the shareholders' return and risk. If there was a lack of planning in capital structure, they may face financing problems for their business activities and cannot use their funds perfectly. 
There are a lot of studies have discussed the importance of capital structure which can be enhanced by issuing debt financing and equity financing. The amount of debt financing or equity financing has many different meanings of risks and benefits (Yazdanfar \& Öhman, 2015). According to the pecking order theory, the companies will prefer retaining earnings then debt financing and finally equity financing because debt financing is cheaper than equity financing (Myers \& Majluf, 1984). Thus, it was important for the companies to make prudent decisions to establish the best capital structure to improve the companies' performance and maximize the wealth of shareholders.

Nowadays, debt financing was prevalent because of tax benefits and lower risk to debtors (Zaidi, Jais \& Karim, 2019). Although debt financing is cheap and has tax incentives, debt financing should not be used exclusively but should be used within a firm to achieve the best firm performance. Since choosing the right capital structure is crucial, companies must become very competitive and cautious in order to survive in a challenging market and attract more investors to expand or develop their business. As everything moves rapidly, companies must formulate a clear strategic capital structure strategy to maintain agility and competitiveness in the rapidly developing technological and economic uncertainties.

The relationship between debt financing and firm performance is vital and often discussed in managerial finances. Most of the previous researches are discussed other countries such as Pakistan but not included Malaysia. Thus, the purpose of this study was to investigate the relationship between debt financing and firm performance of property sectors in Malaysia from 2015 to 2019.

\section{LITERATURE REVIEW}

There are many previous researches that investigated the relationship between the firms' debt level and performance. The company's capital structure is important because it maximizes wealth and minimizes the cost of capital. According to Nazir, Azam and Khalid (2021), the purpose of empirical findings was to examine the relationship between listed firm debt level and performance of manufacturing sectors in Pakistan from 2013 to 2017. The pooled ordinary least square regression and fixed-effect and random-effect models have been used in this finding. The result shows that both short-term debt and long-term debt have negative and significant impacts on firm performance in profitability. However, the findings also showed that firm size has positive and significant effects on profitability. It means that the greater the firm size, the better the firm performance.

Aziz and Abbas (2019) found that firm performance in 14 sectors of the Pakistan Stock Exchange from 2006 to 2014 is significant and negatively related to the short-term and long-term debt. The increase in debt causes a decrease in the performance of the companies because debt is an expensive source of finance. However, the findings revealed that there was a significant and positive relationship between the firm size and firm performance as the results showed that the increase in the firm size will cause the gross profit to rise $23 \%$. Besides that, the research was also supported by the following research finding, Pham and Nguyen (2020) found that debt financing has a statistically significant and negative effect on the Return on Assets (ROA) of Vietnam firms from 2013 to 2017. The result can be concluded that debt financing will bring hurt to the profitability of listed companies.

The research from Yazdanfar and Öhman (2015) is about debt financing and firm performance regard to Swedish small and medium companies in five industry sectors from 2009 to 2012. The result shows that 
account payable, short-term debt and long-term debt are significantly and negative toward profitability. However, the effect of firm size on profitability was significant and positive. Furthermore, the finding from Habib, Khan and Wazir (2016) indicated that there was a significant but negative relationship between shortterm debt and long-term debt with the profitability of the non-financial sector in Pakistan from 2003 to 2012. The higher the debt will affect the lower the profitability. However, the result of the findings indicated that firm size has a positive and significant effect on profitability.

Based on the research from Zaidi et al. (2019), the results showed the short-term debt and long-term debt are significantly and positively related to the firm performance of the consumer product industry in Malaysia from 2001 to 2015 . However, there was a positive but not significant correlation between account payable and firm performance. Similarly, the relationship between firm size and the firm performance of the consumer product industry was positive but insignificant.

\section{Pecking Order Theory}

Pecking order theory has introduced by Donaldson in 1961 and later modified by Stewart Myers and Nicolas Majluf in 1984. The pecking order theory shows that when a company considers how to finance the project, there will be a mode of choosing the source of financing. Based on this theory, companies should raise the funds by retaining earning, debt and equity as the firm will prefer to choose retaining earning (Aziz \& Abbas, 2019). According to Myers and Majluf (1984), companies will first choose the internal financing rather than external financing. For example, the result of research from Habib et al. (2016); Yazdanfar and Öhman (2015) shows that firms prefer internal financing over the outside financing option. When internal funds is insufficient, the external funds are required. The companies prefer debt to equity because the information cost associated with debt issue is lower. The strategy can reduce the costs associated with information asymmetry and agency conflicts. When the proportion of debt in the capital structure was lower will result in high profitability. Therefore, the form of debt will be chosen as a signal of its external financing needs.

\section{METHODOLOGY}

\section{Research Design}

The purpose of this study is to examine the correlation between debt financing and the financial performance of firms in Malaysia. In this study, the data samples that will be chosen are 50 companies within the property sectors listed on the Bursa Malaysia. The time period of the data sample used is from 2015 to 2019. In addition, the dependent variable used in this research is the return on assets (ROA), which is the proxy of the firm performance. Meanwhile, the independent variables that represent debt financing are account payables, short-term debt and long-term debt while the control variable is the firm size. Moreover, the quantitative approach will be applied to conduct this research on how debt financing affects the firms' performance within the property sector in Malaysia. Additionally, there are three regression models will be applied to analyze the data, which are the pooled ordinary least squares (OLS) model, fixed effect model and random effect model. To determine whether the pooled ordinary least squares (OLS) model, fixed effect model and random effect model are the most appropriate, the Hausman test and Breusch-Pagan Lagrange 
Multiplier test will be applied. Lastly, the granger causality test also will be utilized in this research to examine the causality relationship between the dependent and independent variables.

\section{Estimation Model}

In this research, there are one dependent variable, which is the return on assets (ROA) and three independent variables, which are account payables (AP), short-term debt (STD) financing and long-term debt (LTD) financing. We will use the multiple regression model in analyzing the data of all variables selected over the periods. The multiple regression model estimated in this study is expressed as follow:

$$
R O A_{i t}=\beta_{0}+\beta_{1} A P_{i t}+\beta_{2} S T D_{i t}+\beta_{3} L T D_{i t}+\beta_{4} S I Z E_{i t}+\varepsilon_{i t}
$$

Where,

$R O A_{i t}=$ Return on assets of firm $i$ at time $t$

$A P_{i t}=$ Account payables of firm $i$ at time $t$

$S T D_{i t}=$ Short - term debt financing of firm $i$ at time $t$

$L T D_{i t}=$ Long - term debt financing of firm $i$ at time $t$

$S I Z E_{i t}=$ Firm size of firm $i$ at time $t$

$\varepsilon_{i t}=$ Error term

\section{Dependent Variable}

\section{Return on Assets (ROA)}

Return on assets (ROA) is the first main measure and most widely used to represent the profitability of the firm. By using return on assets (ROA), the average amount of profits produced by each unit of assets can be measured. In general, the higher value in return will result in a more efficient management for a company in utilizing its assets (Harelimana, 2017). Hence, the return on assets is a famous indicator that applied to determine the efficiency of a company in managing its assets (Petersen \& Schoeman, 2008). The main parts of the return on assets (ROA) are the net profit and total assets and both of them can be found from the annual report of the companies selected. The formula of the return on assets (ROA) is as follow:

$$
\text { Return on Assets }(R O A)=\frac{\text { Net profit }}{\text { Total assets }}
$$




\section{Independent Variables}

\section{Account Payables (AP)}

As one of the proxy for debt financing, account payables is always used in the previous study, such as the study of Zaidi et al. (2019) as well as Yazdanfar and Öhman (2015). Account payables is a measure that represents the company's responsibility to creditors or suppliers for the goods or services contained in the open accounts. As mentioned by Koshio and Cia (2004), a higher value of account payables may lead to a higher value of cash holdings when taking into account the risks of sustaining the additional cost if negotiating with the suppliers or the risks of making payments with larger amounts in shorter periods than the original expected. Nevertheless, if considering the possibility of delaying payment to the suppliers when it is necessary or possible, a higher value of account payables may also cause a lower value of cash holdings. In this study, the account payables will be indicated as the percentage of the total assets.

\section{Short Term Debt (STD)}

The short-term debt (STD) demonstrates the financial obligations of a company that are expected to be paid off within one year. Based on the research of Hatem (2017), the short-term debt is usually not enough to bring short-term assets and the firm may have a higher amount of financial expenses if it contracts the longterm debt. As a result, the financial performance of the company will be influenced and its profits generated will also be decreased. The short-term debt (STD) is calculated as the short-term debt to total assets ratio, which is shown as follow:

$$
\text { Short }- \text { term debt }(S T D)=\frac{\text { Short }- \text { term debt }}{\text { Total assets }}
$$

\section{Long Term Debt (LTD)}

Different from short-term debt, long-term debt (LTD) refers to the financial obligations that are expected to be paid off by a company with a maturity of more than one year. The study of Hatem (2017) had mentioned that long-term debt will lead to two situations. It may improve the profitability of a firm when the financing cost is lower than the return on the investment project. Otherwise, the company may experience lower financial performance. The long-term debt (LTD) is measured as the long-term debt to total assets ratio, which is shown as follow:

$$
\text { Long }- \text { term debt }(\text { LTD })=\frac{\text { Long }- \text { term debt }}{\text { Total assets }}
$$

\section{Firm Size}

Since the companies may have different sizes either in the same or different industries and this difference will lead to changes in the production cost and profitability of companies. For example, the study of Majumdar (1997) had resulted in that large firms are more profitable than small firms because of more market experience, efficient economic scale, greater market powers and others. In addition, larger companies 
that have greater market power will charge higher prices and gain more profit. Therefore, large companies have more competitive benefits than small companies as small companies faced insufficient organizational resources. In this research, the firm size can be calculated by the natural logarithm of total assets, which is shown as follow:

Firm Size $=$ LnTotal Assets

\section{Pooled Ordinary Least Squares Model}

According to Gujarati (2004), Carl Friedrich Gauss is credited with inventing the method of ordinary least squares (OLS) or linear least square in the late 1700s. It is a measurement instrument that is used in linear regression models to estimate unknown parameters. Furthermore, according to Craven and Islam (2011), the OLS is one of the most basic and important approaches for analysing data and creating Generalized Linear Models, Analysis of Variance (ANOVA), and other procedures. OLS is often used to analyse data for categorization and hypothesis testing purposes. Aside from that, OLS regression is a strong regression technique since it can simply trace the model assumptions. The constant variance, the influence of outliers using basic graphical approaches, and linearity are among the model assumptions.

\section{Fixed Effect Model}

A statistical model in which the model parameters are fixed or non-random values is known as a fixed effect model. Random effect models and mixed models, on the other hand, have all or some of the model parameters as random variables. A fixed effect model refers to a regression model in which the group means are fixed (non-random) as opposed to a random effect model in which the group means are a random sampling from a population in numerous applications including econometrics and biostatistics.

\section{Random Effect Model}

The random effect model, also known as the variance components model, is a statistical model with random variables as model parameters. It's a hierarchical linear model in which the data being analyzed comes from a hierarchy of different populations whose differences are related to the hierarchy. Random effect models are employed in panel analysis of hierarchical or panel data in econometrics when no fixed effects are assumed (it allows for individual effects). A mixed model with random effects is a specific example of a mixed model.

\section{Multicollinearity: Variance Inflation Factor (VIF)}

The Variance Inflation Factor (VIF) is a metric for determining how much multicollinearity there is in a collection of multivariate regression variables. The VIF for a regression model variable is equal to the ratio of the total model variance to the variance of a model that just includes that single independent variable in mathematics. For each independent variable, this ratio is determined. A high VIF shows that the linked independent variable has a high degree of collinearity with the model's other variables. 
Variance inflation factors range from 1 upwards. The numerical value for VIF tells you (in decimal form) what percentage the variance (i.e. the standard error squared) is inflated for each coefficient. For example, a VIF of 1.9 tells you that the variance of a particular coefficient is $90 \%$ bigger than what you would expect if there was no multicollinearity - if there was no correlation with other predictors.

A rule of thumb for interpreting the variance inflation factor:

- $1=$ not correlated.

- Between 1 and 5 = moderately correlated.

- Greater than 5 = highly correlated.

\section{Granger Causality Test}

Granger causality test is a test used to investigate the capacity to forecast the future values of time series by using the past values of another time series (Granger, 1969). In general, the Granger causality test may be divided into two types: unidirectional causality and bilateral causality. According to this definition, unidirectional causality occurs when there is just one cause and effect relationship between the independent variable (IV) and the dependent variable (DV). Either the IV causes the DV or the DV has an impact on the IV. Bilateral causality is a two-way link between two variables in which the IV causes the DV while simultaneously having an influence on the DV. The hypothesis for the Granger causality test are structured as follows:

\section{$H_{0}$ : Variable $X$ does not granger causes the variable $Y$. \\ $H_{1}$ : Variable $X$ does granger causes the variable $Y$.}

If the probability value is less than the significance level $(\alpha)$ of 0.01 or the test statistic value is more than the critical value, the Granger Causality test decision rule is to reject the null hypothesis $\left(\mathrm{H}_{0}\right)$. Otherwise, $\mathrm{H}_{0}$ should not be rejected.

\section{FINDINGS \& DISCUSSION}

\section{Descriptive Statistics}

Descriptive statistics are brief descriptive coefficients that summarize a given data set, which can be either a representation of the entire or a sample of a population. Descriptive statistics are broken down into measures of central tendency and measures of variability (spread). Measures of central tendency include the mean, median, and mode, while measures of variability include standard deviation, variance, minimum and maximum variables, kurtosis, and skewness. A given data set has been summarized to a systematic descriptive statistic as shown in Table 4.1 and the descriptive statistics show the behavior of the whole observation for 5 years period.

Table 1 showed the descriptive statistics for return on assets, account payables, long-term debt and short-term debt of 50 property companies in Malaysia. The mean value of return on asset was 1.14. The maximum and minimum number were 3.51 and -2.57 respectively. The median value of return on assets was 1.31 . 
The mean value of account payable was 10.36 which is higher than the mean value of return on asset. In addition, it had a median value of 9.17. The highest account payable from 2015 to 2019 was 38.44 while the lowest account payable in the same period was 0.16 .

Table 1: Summary of descriptive statistics

\begin{tabular}{|l|c|c|c|c|c|}
\hline & LROA & AP & LTD & STD & SIZE \\
\hline Mean & 1.136367 & 10.35828 & 20.08181 & 22.92623 & 9.278524 \\
\hline Median & 1.308953 & 9.169705 & 19.86607 & 20.80625 & 9.216633 \\
\hline Maximum & 3.508940 & 38.44993 & 56.89506 & 58.58206 & 10.52670 \\
\hline Minimum & -2.568827 & 0.155610 & 0.003824 & 2.468375 & 8.012917 \\
\hline Std. Dev. & 0.954473 & 6.658870 & 11.95711 & 11.86862 & 0.512098 \\
\hline Skewness & -0.776480 & 1.180548 & 0.472539 & 0.708343 & 0.185714 \\
\hline Kurtosis & 3.956186 & 4.929677 & 3.000484 & 3.198841 & 2.954797 \\
\hline
\end{tabular}

Note: $\mathrm{LROA}=$ Log return on assets; AP=Account payables; LTD=Long term debt; STD=Short term debt; SIZE=Firm size.

Furthermore, the mean value of long-term debt was 20.08 and it had a median value of 19.87 which was higher than the median value of return on asset and account payable. 56.90 and 0.0038 were the maximum and minimum value of long-term debt respectively.

In addition, the mean value of short-term debt was 22.93 whereas the median value was 20.81 . The maximum and minimum values of the short-term debt were 58.58 and 2.47 respectively. The mean and median values of short-term debt were the highest as compared to the return on assets, account payables, longterm debt and firm size from 2015 to 2019.

For the firm size, its mean value was 9.28 while the median value was 9.22. The maximum and minimum values of the firm size within these five years periods were 10.53 and 8.01 respectively.

\section{Correlation Matrix}

Table 2: Results of correlation matrix

\begin{tabular}{|c|c|c|c|c|c|}
\hline & LROA & AP & STD & LTD & SIZE \\
\hline LROA & 1.000000 & - & - & - & - \\
\hline AP & -0.135749 & 1.000000 & - & - & - \\
\hline STD & -0.028203 & 0.491005 & 1.000000 & - & - \\
\hline LTD & -0.109455 & -0.145334 & 0.066026 & 1.000000 & - \\
\hline SIZE & -0.055596 & -0.030177 & 0.047652 & 0.165577 & 1.000000 \\
\hline
\end{tabular}

Note: $\mathrm{LROA}=\mathrm{Log}$ return on assets; AP=Account payables; LTD=Long term debt; STD=Short term debt; SIZE=Firm size.

Based on Table 2 above, the results of the correlation matrix have indicated a negative relationship between the account payables and return on assets with a coefficient of -0.1357 . Next, the correlation between the long-term debt and return on assets has resulted in a coefficient of -0.1095 . This indicates that these two variables were negatively correlated. Moreover, the short-term debt and return on assets also recorded a negative correlation with a coefficient of -0.0282 . These two variables have the lowest correlation and among each as compared to other variables like long-term debt, account payables and firm size. For the firm size, it also inversely associated with the return on assets with a coefficient of - 0.0556 . In short, the outcomes of the 
correlation matrix revealed that the return on assets has a negative correlation with all the independent variables.

\section{Regression Analysis}

Table 3 shows the regression results of the three models, which are the pooled ordinary least squares (OLS) model, fixed effect model and random effect model. According to Table 4.3, the fixed effect model was the most suitable one among the three regression models. The outcome of the Breusch-Pagan Lagrange Multiplier test has proved that the random effect model is more suitable than the pooled OLS model as the pvalue (0.0000) is lower than 0.05 of the significant level. However, the results of the Hausman test show that the p-value (0.0030) is smaller than the significant level (0.05) and this means that the fixed effect model is more appropriate as compared to the random effect model. Additionally, since the variance inflation factor of variables is lower than 10 , so there is no problem with multicollinearity.

Table 3: Regression results of pooled OLS, fixed effect and random effect models

\begin{tabular}{|c|c|c|c|c|c|}
\hline Variables & $\begin{array}{l}\text { Model 1: } \\
\text { Pooled OLS }\end{array}$ & $\begin{array}{l}\text { Model 2: } \\
\text { Fixed effect }\end{array}$ & $\begin{array}{c}\text { Model 3: } \\
\text { Random effect }\end{array}$ & \multicolumn{2}{|c|}{$\begin{array}{c}\text { Collinearity Statistics tolerance: } \\
\text { VIF }\end{array}$} \\
\hline \multicolumn{6}{|l|}{$\begin{array}{l}\text { Dependent } \\
\text { Variable: LROA }\end{array}$} \\
\hline $\mathrm{C}$ & $\begin{array}{c}2.238364 * \\
(0.0415)\end{array}$ & $\begin{array}{c}18.29182^{*} \\
(0.0002)\end{array}$ & $\begin{array}{c}3.235386^{*} \\
(0.0337)\end{array}$ & & \\
\hline $\mathbf{A P}$ & $\begin{array}{c}-0.028022^{*} \\
(0.0082)\end{array}$ & $\begin{array}{c}-0.016619 \\
(0.3721)\end{array}$ & $\begin{array}{c}-0.019454 \\
(0.1133)\end{array}$ & 0.7265 & 1.3764 \\
\hline STD & $\begin{array}{l}0.006337 \\
(0.2802)\end{array}$ & $\begin{array}{l}0.009833 \\
(0.3734)\end{array}$ & $\begin{array}{l}0.003372 \\
(0.6260)\end{array}$ & 0.7380 & 1.3550 \\
\hline LTD & $\begin{array}{c}-0.010856^{*} \\
(0.0369) \\
\end{array}$ & $\begin{array}{l}0.013115 \\
(0.1715) \\
\end{array}$ & $\begin{array}{c}-0.004820 \\
(0.4213)\end{array}$ & 0.9314 & 1.0736 \\
\hline SIZE & $\begin{array}{c}-0.079649 \\
(0.5015)\end{array}$ & $\begin{array}{c}-1.883070^{*} \\
(0.0004)\end{array}$ & $\begin{array}{l}-0.202406 \\
(0.2197)\end{array}$ & 0.9704 & 1.0305 \\
\hline Adjusted $\mathbf{R}^{2}$ & 0.025929 & 0.316799 & 0.002745 & & \\
\hline F-Statistics & 2.657041 & 3.178505 & 1.171318 & & \\
\hline DW- Statistics & 1.390739 & 2.429346 & 1.885470 & & \\
\hline $\begin{array}{l}\text { Hausman Test } X^{2} \\
\text { Sig }\end{array}$ & & $\begin{array}{c}15.994503 \\
(0.0030)\end{array}$ & & & \\
\hline $\begin{array}{l}\text { Breusch-Pagan LM } \\
\text { Test }\end{array}$ & & $\begin{array}{c}34.80379 \\
(0.0000)\end{array}$ & & & \\
\hline $\mathbf{N}$ & 250 & 250 & 250 & & \\
\hline
\end{tabular}

Note: $\mathrm{LROA}=\mathrm{Log}$ return on assets; $\mathrm{AP}=$ Account payables; LTD=Long term debt; STD=Short term debt; SIZE=Firm size.

Variables are significant at $* \mathrm{p}<0.05$ significance level.

In the fixed effect model, the account payables (AP) was not statistically significant and negatively associated with return on assets (ROA). This is because the p-value (0.3721) is greater than the significance level (0.05) and has a coefficient of -0.016619. Similarly, the firm size (SIZE) also resulted in a negative effect on return on asset (ROA), but both variables are statistically significantly associated as the p-value $(0.0004)$ is smaller than the $5 \%$ significance level. On the contrary, there was positive association existed 
between the short-term debt (STD) and return on asset (ROA) with a coefficient of 0.009833. However, the short-term debt (STD) was also not statistically significant at the 5\% significance level because the p-value (0.3734) is greater than the significance level (0.05). Lastly, the long-term debt (LTD) also not statistically significant and positively correlated with return on assets (ROA) with a coefficient of 0.013115 . The p-value of the long-term debt (LTD) is 0.1715 , which is greater than the 5\% significance level. Overall, the results show all the independent variables had no significant effect on return on asset (ROA) except the firm size. Lastly, the adjusted $\mathrm{R}^{2}$ was 0.3168 , which means that $32 \%$ of the variations in the return on assets is explained by the fixed effect model.

\section{Granger Causality Test}

According to the results of granger causality test showed in Table 4, most of the observations have shown an independence relationship and there is only one unidirectional causality relationship can be observed among these five variables. As a result, the null hypothesis of "LTD does not granger cause STD" can be rejected, which means that the short-term debt is affected by the long-term debt. Additionally, the results also indicate that the return on assets does not affected by the account payables, short-term debt, longterm debt and firm size.

Table 4: Results of Granger Causality Test

\begin{tabular}{|c|c|c|}
\hline $\begin{array}{ll}\text { Null Hypothesis } \\
\end{array}$ & Probability & Conclusion \\
\hline AP does not granger cause LROA & 0.5357 & No granger cause \\
\hline LROA does not granger cause AP & 0.5277 & No granger cause \\
\hline LROA does not granger cause LTD & 0.8312 & No granger cause \\
\hline STD does not granger cause LROA & 0.3283 & No granger cause \\
\hline AP does not granger cause LTD & 0.0873 & No granger cause \\
\hline STD does not granger cause AP & 0.6056 & No granger cause \\
\hline AP does not granger cause STD & 0.6692 & No granger cause \\
\hline STD does not granger cause LTD & 0.0629 & No granger cause \\
\hline SIZE does nor granger cause AP & 0.5390 & No granger cause \\
\hline AP does nor granger cause SIZE & 0.1000 & No granger cause \\
\hline SIZE does nor granger cause STD & 0.9984 & No granger cause \\
\hline STD does nor granger cause SIZE & 0.8577 & No granger cause \\
\hline SIZE does nor granger cause LTD & 0.8358 & No granger cause \\
\hline LTD does nor granger cause SIZE & 0.4470 & No granger cause \\
\hline
\end{tabular}

Note: $\mathrm{LROA}=\mathrm{Log}$ return on assets; $\mathrm{AP}=\mathrm{Account}$ payables; $\mathrm{LTD}=$ Long term debt; STD=Short term debt; SIZE=Firm size. 


\section{CONCLUSION AND RECOMMENDATIONS}

This research aims to examine the influence of debt financing on the financial performance of property companies from 2015 to 2019. A sample of 50 listed non-financial companies produced a total of 250 balanced observations for analysis. The results show that there are positive and insignificant impacts existed between the short-term and long-term debt with the company's performance. This means that the companies can maintain their debt level at a suitable level to increase the market value and performance as well as not damage the companies' benefits. The findings of both short-term and long-term debt are consistent with the results of Zaidi et al. (2019) which indicate that the short-term and long-term debt have positive impacts on firms' performance, but the difference is both variables are statistically significant in their studies whereas not statistically significant in this study. In contrast, the account payables and firm size demonstrates an inverse association with profitability. This means that the declining account payables and firm size will bring the increase in the financial performance.

There are some limitations to this research. Firstly, the time period of the selected data sample is limited to five years periods, which is from 2015 to 2019. This may not comprehensively in analyzing how the debt level in a company influences its performance. Moreover, the data sample selected only focuses on the listed companies within the property sectors in Malaysia. The limitation of the analyzed sector may lead to fewer comparisons of the data with other sectors in Bursa Malaysia and then cause a less detailed analysis. Therefore, future academicians should consider using a longer time period and data of different sectors in their analysis, so that the analysis can be improved and results in a more detailed analysis. Apart from the limitations, these empirical results may provide some useful managerial implications to the executive managers in maintaining the company's debt level at an optimum level to maximize their benefits. With a clear understanding of the effects of debt financing on profitability, managers can take more appropriate actions when they make financing or investing decisions. In addition, this research also can be a reference to the future academicians for further researches that relevant to debt financing or profitability.

\section{REFERENCES}

Aziz, S., \& Abbas, U. (2019). Effect of Debt Financing on Firm Performance: A Study on Non-Financial Sector of Pakistan. Open Journal of Economics and Commerce, 2(1), 8-15.

Craven, B. D., \& Islam, S. M. (2011). Ordinary least-squares regression (pp. 224-228). Sage Publications.

Granger, C. W. (1969). Investigating causal relations by econometric models and crossspectral methods. Econometrica: Journal of the Econometric Society, 37(3), 424-438.

Gujarati, D. N. (2004). Basic Econometrics. Retrieved from http://zalamsyah.staff.unja.ac.id/wpcontent/uploads/sites/286/2019/11/7-Basic- Econometrics-4th-Ed.-Gujarati.pdf

Habib, H., Khan, F., \& Wazir, M. (2016). Impact of debt on profitability of firms: Evidence from non-financial sector of Pakistan. City University Research Journal, 6(1).

Harelimana, J. B. (2017). Effect of debt financing on business performance: A comparative study between I\&M Bank and Bank of Kigali, Rwanda. Global Journal of Management and Business Research, $17(2), 37-45$. 
Hatem, B. S. (2017). Influence of debt maturity on firm performance: An International Comparison. International Journal of Economics and Finance, 9(5), 106-113.

Koshio, S., \& Cia, J. D. S. (2004). The determinants of corporate cash holdings: a comparison between Brazilian and US firms. Anais do Encontro Nacional dos Programas de Pós-Graduação em Administração-ENANPAD, São Paulo.

Majumdar, S. K. (1997). The impact of size and age on firm-level performance: some evidence from India. Review of industrial organization, 12(2), 231-241.

Modigliani, F., \& Miller, M. H. (1958). The Cost of Capital, Corporation Finance and the Theory of Investment. The American Economic Review, 48(3), 261-297.

Moreno, R. (1998). What Caused East Asia's Financial Crisis? Federal Reserve Bank of San Francisco Economic Letter.

Myers, S. C., \& Majluf, N. S. (1984). Corporate financing and investment decisions when firms have information that investors do not have. Journal of financial economics, 13(2), 187-221.

Nazir, A., Azam, M. \& Khalid, M. U. (2021). Debt financing and firm performance: empirical evidence from the Pakistan Stock Exchange. Asian Journal of Accounting Research.

Pham, H. S. T., \& Nguyen, D. T. (2020). Debt financing and firm performance: The moderating role of board independence. Journal of General Management, 45(3), 141-151.

Petersen, M. A., \& Schoeman, I. (2008). Modeling of banking profit via return-on-assets and return-on-equity. Proceedings of the World Congress on Engineering, 2, 1-6.

Salim, M., \& Yadav, R. (2012). Capital structure and firm performance: Evidence from Malaysian listed companies. Procedia-Social and Behavioral Sciences, 65, 156-166.

Yazdanfar, D., \& Öhman, P. (2015). Debt financing and firm performance: an empirical study based on Swedish data. The Journal of Risk Finance, 16(1), 102-118.

Zaidi, N. S. B., Jais, M. bin, \& Karim, B. bin A. (2019). The Influence of Debt Financing on Firms' Performance: A Study of Consumer Product Industry in Malaysia. International Journal of Academic Research in Business and Social Sciences, 9(9), 578-589. 